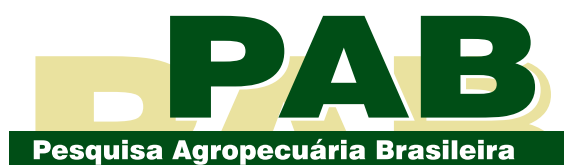

ISSN 1678-3921

Journal homepage: www.embrapa.br/pab

For manuscript submission and journal contents, access: www.scielo.br/pab
Thematic Issue - Regional Agrominerals/ Original Article

\section{Ecotoxicological assessment of silicate rock fertilizers using soil invertebrates}

\begin{abstract}
The objective of this work was to evaluate the possible adverse effects of rock dusts on the avoidance behavior of earthworms and collembolans, as well as on the survival and reproduction of enchytraeids, in ecotoxicological tests using artificial and natural soils. The tests were performed following international guidelines (ISO 17512-2/2011, ISO 11267/1999, and NBR ISO 16387/2012), with some adaptations, in order to evaluate the effect of dusts from two silicate rocks, biotite schist and phonolite, at the concentrations of 0 , $0.1,1.0,10$, and 100\%, in artificial and natural (Arenosol and Ferralsol) soils. The avoidance behavior of the earthworm Eisenia andrei and the collembolan Folsomia candida was evaluated, as well as the survival and reproduction of the enchytraeid Enchytraeus sp. Biotite schist and phonolite affected negatively earthworms when applied to the soil at concentrations equal to or higher than $1.0 \%$. The observed effect was associated to the greater presence of salts, especially in the phonolite, and to changes in soil texture when higher concentrations were used. Negative effects on collembolans and enchytraeids were verified at concentrations of $10 \%$ or using pure rock dusts. Agronomic rates smaller than $1.0 \%$ (approximately $20 \mathrm{Mg} \mathrm{ha}^{-1}$ ) rock dusts do not cause avoidance behavior or reduction in the survival and reproduction of invertebrates in the soil.
\end{abstract}

Index terms: agrominerals, collembolans, earthworms, ecotoxicology, enchytraeids, soil fauna.

\section{Avaliação ecotoxicológica de fertilizantes de rocha de silicato com uso de invertebrados de solo}

Resumo - O objetivo deste trabalho foi avaliar os efeitos adversos potenciais de agrominerais sobre o comportamento de fuga de minhocas e colêmbolos, bem como a sobrevivência e a reprodução de enquitreídeos, em testes ecotoxicológicos com solos artificial e natural. Os testes foram realizados seguindo normas internacionais (ISO 17512-2/2011, ISO 11267/1999 e NBR ISO 16387/2012), com algumas adaptações, para avaliar o efeito de pós de duas rochas silicáticas, biotita xisto e fonolito, nas concentrações de 0 , 0,1, 1,0, 10 e $100 \%$, em solos artificial e naturais (Neossolo e Latossolo). Foram avaliados o comportamento de fuga da minhoca Eisenia andrei e do colêmbola Folsomia candida, além da sobrevivência e da reprodução do enquitreídeo Enchytraeus sp. Biotita xisto e fonolito afetaram negativamente o comportamento das minhocas quando aplicados no solo, em concentrações iguais ou superiores a 1,0\%. O efeito observado foi associado à maior presença de sais, principalmente no fonolito, e a mudanças na textura do solo quando concentrações maiores foram usadas. Efeitos negativos em colêmbolos e enquitreídeos foram verificados em concentrações de $10 \%$ ou com pós de 
rocha puros. Doses agronômicas com concentrações menores que $1,0 \%$ de pós de rocha (aproximadamente $20 \mathrm{Mg} \mathrm{ha}^{-1}$ ) não causam comportamento de fuga ou redução na sobrevivência e na reprodução de invertebrados no solo.

Termos para indexação: agrominerais, colêmbolos, minhocas, ecotoxicologia, enquitreídeos, fauna do solo.

\section{Introduction}

Silicate agrominerals are rock dusts used to enhance agriculture production by slowly releasing their nutrients, which improves soil aeration and increases soil $\mathrm{pH}$ (Van Straaten, 2006). They are products and by-products of silicate rock mining, which can be applied to improve soil fertility and health as part of an environmental sustainability strategy (Martins et al., 2010; Blaskowski et al., 2019).

Because Brazil is dependent on external sources of potassium (Guareschi et al., 2019), silicate agrominerals as sources of $\mathrm{K}$ are an interesting local alternative to help in the restoration of poorly fertilized soils (Martins et al., 2010). Pyroclastic rock, biotite schist, and ultramafic alkaline rocks release $\mathrm{K}$ and cause a residual effect on subsequent crops (Martins et al., 2010). Biotite and feldspathoid, for example, release $\mathrm{K}$ more easily to soils and plants than other minerals (Resende et al., 2006).

However, although the use of rock dusts in agricultural soils can be considered as a low impact and eco-friendly strategy, since the materials produced in mining or industrial sites are reused, caution is still necessary. Some of these materials may be potentially toxic to plants, animals and microorganisms, depending on the amount applied, the dissolution kinetics of the elements present in them (e.g., heavy metals, salts, and radionuclides), their interactions with the environment, and the inherent sensitivity of the organism exposed to them (Djurišić et al., 2015).

In Brazil, the use of silicate agrominerals is currently regulated by the Ministry of Agriculture, Livestock and Food Supply and by the Ministry of Mines and Energy (Brasil, 2016). Those kinds of products undergo a series of chemical, physical, and mineralogical analysis for their characterization, and, if the imposed limits are passed, they are subjected to plant growth tests before they can be registered as a soil remineralizer (Brasil, 2016). To be registered, the rocks need to be classified according to their quality as agrominerals and to the risks presented to human and animal health, as well as to the environment, but no specific rate is recommended.

Even though many tests are performed to register an agromineral, it is also important to evaluate possible side effects of their application, in order to better understand and foresee their impact on the soil environment. This procedure, however, is not required by Brazilian legislation. Despite the potential benefits attributed to the use of agrominerals, such as the reduction of carbon emissions while improving productivity, Edwards et al. (2017) pointed, as a pitfall, the lack of information on biodiversity impacts on agricultural and natural areas.

Obtaining this information is fundamental, since soil supports most of the worldwide biodiversity. Hundreds of thousands of species of soil invertebrates contribute to organic matter decomposition, nutrient cycling, soil structure, and other important functions that provide ecosystem services (Brown et al., 2015). However, these functions can be impaired by different agricultural practices and soil management systems that can modify the habitat of soil biota and, consequently, cause adverse effects and impacts on the sustainability of a production system (Baretta et al., 2014).

In this context, some international protocols have been developed to investigate if a specific material can potentially affect soil biota. For pesticide registration, for example, several internationally standardized tests are required to determine the potential adverse effects on different aquatic and terrestrial nontarget organisms, including plants, animals, and microorganisms. These standardized methods with materials rich in salts can affect nontarget soil organisms, depending on the concentration of salts, the combination with other substances in the soil, and the sensitivity of the organisms (Owojori \& Reinecke, 2014; Alves et al., 2015; Machado et al., 2018). Among soil organisms, earthworms are the most commonly tested; however, enchytraeids, collembolans, mites, isopods, and other invertebrates are also used worldwide to assess the potential risk of certain materials or to evaluate how much the soil of a contaminated area is harmful to soil biota (Niva \& Brown, 2019).

Therefore, it is important to assess the potential risks to soil invertebrates due to agrominerals, such as biotite schist and phonolite, used as sources of $\mathrm{K}$ for 
agricultural purposes in Brazil. The hypothesis is that agrominerals do not cause adverse effects on different invertebrates.

The objective of this work was to evaluate the possible adverse effects of rock dusts on the avoidance behavior of earthworms and collembolans, as well as on the survival and reproduction of enchytraeids, in ecotoxicological tests with artificial and natural soils.

\section{Materials and Methods}

For the experiment, three soils types were used. The first was a tropical artificial soil (TAS) made up of $75 \%$ fine sand (quartz, $\mathrm{SiO}_{2}$ ), 20\% kaolin (with at least 30\% kaolinite), and 5\% ground coconut shell fiber (ABNT, 2012; Niva \& Brown, 2019). Soil $\mathrm{pH}$ was corrected to $6.0 \pm 0.5$ by adding $\mathrm{CaCO}_{3}$ when needed. The other two soils were natural. For the tests with enchytraeids, a Latossolo Vermelho-Amarelo (Santos et al., 2018), i.e., a Ferralsol (IUSS Working Group WRB, 2015), was collected at $0-20 \mathrm{~cm}$ depth at the experimental field of Embrapa Cerrados, located in Planaltina, in Distrito

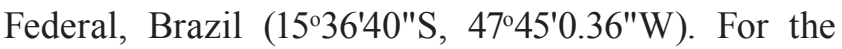
tests with collembolans and earthworms, a Neossolo Quartzarênico (Santos et al., 2018), i.e., an Arenosol (IUSS Working Group WRB, 2015), was collected in the municipality of Ararangua, in the state of Santa Catarina, also Brazil (2900'20"S, 49 $\left.31^{\prime} 03^{\prime \prime} \mathrm{W}\right)$, at the same depth as the Ferralsol, air dried, defaunated by freeze-thaw cycles, and sieved using a $2 \mathrm{~mm}$ mesh, following standard NBR ISO 16387, as recommended by Associação Brasileira de Normas Técnicas (ABNT, 2012; Niva \& Brown, 2019). Both soils were from uncontaminated areas. The results of the soil chemical and texture analyses are shown in Table 1.

The water holding capacity of the soils or rock dust substrates was adjusted to $50 \%$ for the tests with enchytraeids, according to NBR ISO 16387 (ABNT, 2012; Niva \& Brown, 2019), and to 55\% for the earthworm and collembolan tests, following ISO 11267 (ISO, 1999).

The test soils were prepared with the TAS or natural soil mixed with different concentrations $(\mathrm{v} / \mathrm{v})$ of rock dust: $0.1,1.0,10,100 \%$ dry-mixed ground rock; the control consisted of $0 \%$ rock (TAS or natural soil only). Test soil batches for each concentration were prepared 20 days before the tests. The soils were moistened in the recommended range; however, $10 \%$ of the water were added a week before for the chemical stabilization of the material. The evaluated soil was distributed in vials according to the recommendations for each studied species, as follows.

The assessed silicate agrominerals, biotite schist and phonolite, were obtained from mines in the Brazilian states of Goiás and Minas Gerais, respectively. Rocks were ground and sieved, resulting in a dust with particles smaller than $0.3 \mathrm{~mm}$ for biotite and than $0.15 \mathrm{~mm}$ for phonolite, being subjected to a chemical analysis afterwards (Table 2).

The evaluated invertebrates were: the earthworm Eisenia andrei Bouché 1972, the collembolan (springtail) Folsomia candida Willem 1902, and an enchytraeid (potworm) of the Enchytraeus sp.

The earthworms of the species E. andrei were mass reared in a laboratory in a dried and sieved substrate composed of horse manure, powdered coconut shell fiber, and fine sand, at a ratio of 2:1:0.15 dry weight, respectively. The worms were fed with oat flakes moistened with deionized water and were kept in a room under $20 \pm 2^{\circ} \mathrm{C}$ and 12 hours light: 12 hours dark, as described in Segat et al. (2015).

Collembolans of the species $F$. candida were mass reared in plastic boxes containing a mixture of

Table 1. Chemical and texture characteristics of the soils used as test substrates, as well as electrical conductivity (CE) and total dissolved solids (TDS).

\begin{tabular}{|c|c|c|c|}
\hline Characteristic $^{(1)}$ & Ferralsol & Arenosol & $\operatorname{TAS}^{(2)}$ \\
\hline Organic matter $(\%)$ & 2.1 & 1.1 & 4.9 \\
\hline Cation exchange capacity $\left(\mathrm{cmol}_{\mathrm{c}} \mathrm{dm}^{-3}\right)$ & 5.1 & 3.84 & 70.5 \\
\hline $\mathrm{K}\left(\mathrm{cmol}_{\mathrm{c}} \mathrm{dm}^{-3}\right)$ & 0.03 & 0.02 & 0.06 \\
\hline $\mathrm{Ca}\left(\mathrm{cmol}_{\mathrm{c}} \mathrm{dm}^{-3}\right)$ & 0.07 & 0.7 & 14 \\
\hline $\operatorname{Mg}\left(\mathrm{cmolc} \mathrm{dm}{ }^{-3}\right)$ & 0.05 & 0.2 & 9 \\
\hline $\mathrm{pH}$ (water) & 4.7 & 4.8 & 6.2 \\
\hline $\mathrm{H}+\mathrm{Al}\left(\mathrm{cmol}_{\mathrm{c}} \mathrm{dm}^{-3}\right)$ & 5 & 2.8 & 22 \\
\hline $\mathrm{CE}\left(\mu \mathrm{S} \mathrm{cm}{ }^{-2}\right)$ & 54 & - & 90 \\
\hline TDS (mg L-1) & 25 & - & 43 \\
\hline Clay $\left(\mathrm{g} \mathrm{kg}^{-1}\right)$ & 153 & 80 & $200^{(3)}$ \\
\hline Sand $\left(\mathrm{g} \mathrm{kg}^{-1}\right)$ & 843 & 370 & 750 \\
\hline Silt $\left(\mathrm{g} \mathrm{kg}^{-1}\right)$ & 4 & 550 & 0 \\
\hline
\end{tabular}

${ }^{(1)}$ The analysis followed the protocols described in Claessen (1997). (2) Tropical artificial soil, composed of $75 \%$ fine sand (quartz), $20 \%$ kaolin (with at least 30\% kaolinite), and 5\% ground coconut shell fiber. ${ }^{(3)}$ Kaolin. 
activated charcoal (dust), water, and plaster of Paris at a ratio of 1:7:11 $(\mathrm{w} / \mathrm{w} / \mathrm{w})$, being kept in a room under $20 \pm 2^{\circ} \mathrm{C}$ and 12 hours light:12 hours dark. They were fed with dried baker's yeast.

The culture of the enchytraeids of the species Enchytraeus sp. was established in 2008 from a single worm sampled in the municipality of Piraquara, in the state of Paraná, Brazil, and its offspring. Several individuals of the culture were analyzed by Rüdiger Maria Schmelz, a taxonomist of Universidade da Coruña, who confirmed it was an undescribed species of the genus. The culture was kept in $0.8-1.0 \%$ agar plates prepared with mineral water and covered with a thin layer of the TAS under $20 \pm 2^{\circ} \mathrm{C}$, being fed with fine oatmeal. The duration of the life cycle of the enchytraeids was 20 days. Ten days before the test, the culture was transferred to $25 \pm 2^{\circ} \mathrm{C}$ for an adaptation period to the test temperature.

Table 2. Chemical composition, $\mathrm{pH}$, electrical conductivity (EC), and total dissolved solids (TDS) of the silicate agrominerals used in the experiments.

\begin{tabular}{|c|c|c|}
\hline $\operatorname{Oxide}^{(1)}(\%)$ & Biotite schist & Phonolite \\
\hline $\mathrm{SiO}_{2}$ & 57.8 & 54.0 \\
\hline $\mathrm{Al}_{2} \mathrm{O}_{3}$ & 17.1 & 20.7 \\
\hline $\mathrm{Fe}_{2} \mathrm{O}_{3}$ & 9.0 & 4.0 \\
\hline $\mathrm{K}_{2} \mathrm{O}$ & 3.2 & 8.4 \\
\hline $\mathrm{Na}_{2} \mathrm{O}$ & 2.3 & 7.5 \\
\hline $\mathrm{CaO}$ & 1.8 & 1.5 \\
\hline $\mathrm{MgO}$ & 4.8 & 0.2 \\
\hline $\mathrm{P}_{2} \mathrm{O}_{5}$ & 0.2 & 0.1 \\
\hline $\mathrm{MnO}$ & 0.1 & 0.3 \\
\hline $\mathrm{TiO}^{(2)}$ & 0.9 & 0.6 \\
\hline $\mathrm{LOI}^{(2)}$ & 2.5 & 2.5 \\
\hline Total (\%) & 99.7 & 99.8 \\
\hline $\mathrm{pH}(\text { water })^{(3)}$ & 8.2 & 9.4 \\
\hline $\mathrm{EC}\left(\mathrm{uS} \mathrm{cm}^{-1}\right)^{(3)}$ & 91 & 255 \\
\hline TDS $\left(\mathrm{mg} \mathrm{L}^{-1}\right)^{(3)}$ & 43 & 122 \\
\hline
\end{tabular}

${ }^{(1)}$ The analyses were performed by the SGS-Geosol laboratory (Vespasiano, MG, Brazil) using wavelength dispersive X-ray fluorescence spectroscopy, on fused glass discs, with $40 \mathrm{~mm}$ diameter, prepared from $0.8 \mathrm{~g}$ sample dust, mixed with $4.5 \mathrm{~g}$ lithium tetraborate flux, and fused in $\mathrm{Pt}-5 \% \mathrm{Au}$ crucibles at $1,120^{\circ} \mathrm{C} .{ }^{(2)} \mathrm{TiO}$, titanium oxide; and LOI, loss of ignition. ${ }^{(3)}$ The analysis was carried out by Embrapa Cerrados, following the protocols described in Claessen (1997).
The avoidance test was performed as described in ISO 17512-2 (ISO, 2011; Niva \& Brown, 2019), but in four replicates because there was a limited amount of uncontaminated natural soil. Twenty collembolans with 10-12 days of age were placed in plastic circular containers $(9 \mathrm{~cm}$ diameter and $6 \mathrm{~cm}$ height), divided in two sections and filled with $30 \mathrm{~g}$ of the control soil (not treated) on one side and the treated soil or rock dust substrate on the other. These test containers were kept in a temperature-controlled room at $20 \pm 2^{\circ} \mathrm{C}$, and no food was added to them. After 48 hours, the treated and untreated soils in each container were separated again by vertically inserting a spacer. Water with some drops of black ink was added to the vials to promote the flotation of the collembolans and allow counting the individuals in each section.

The avoidance test assumes that the individuals should be evenly distributed between the two sections of the container when filled with the same soil on both sides (dual test). Therefore, a dual test was performed for each untreated soil as previously described. The test is considered valid only when the distribution remains between $40-60 \%$ of the individuals in each side, as recommended by ISO 17512-2 (ISO, 2011).

For the avoidance test with earthworms, plastic rectangular containers $\left(23.3 \times 16.7 \mathrm{~cm}^{2}\right.$ area and $7.7 \mathrm{~cm}$ height) were divided in two sections filled with 500 $\mathrm{g}$ (dry weight) of the control soil (not treated) on one side and $500 \mathrm{~g}$ of the test soil (treated) on the other according to NBR ISO 17512-1 (ABNT, 2011; Niva \& Brown, 2019). Subsequently, ten clitellate adult earthworms with a body weight of 250-600 mg were placed on the substrate in each container, right on the line in between the two sections. These containers were kept in a temperature-controlled room at $20 \pm 2^{\circ} \mathrm{C}$, and no food was added. After 48 hours, the treated and untreated soils in each container were separated again by vertically inserting a spacer. The soil of each section was removed to another recipient, and the earthworms were counted. Similar to the test with collembolans, the number of replicates used was reduced to four because there was a limited amount of substrate with the required quality. Dual control and the validation test were performed as described before.

The lethality and reproduction tests with enchytraeids followed the procedures recommended by NBR ISO 16387 (ABNT, 2012; Niva \& Brown, 2019), with some adaptations. The experimental unit 
for both tests consisted of ten adult enchytraeids in 20 $\mathrm{g}$ (dry weight) of the test soil in a glass vial $(8.0 \times 4.0$ $\mathrm{cm}$ diameter). The lethality and reproduction tests were performed with five replicates, in a randomized design, independently. Only clitellate adults, 6.0-8.0 $\mathrm{mm}$ long, were used for the tests. Feeding consisted of $0.3 \mathrm{~g}$ fine oatmeal in each vial at the beginning of the test. At the end of the tests (a period of 7 days for lethality and of 21 for reproduction), 96\% ethanol was added to each vial with a few drops of $0.1 \%$ Bengal rose for fixation and coloring of the enchytraeids, in order to facilitate counting of survivors and juveniles under a stereomicroscope according to Associação Brasileira de Normas Técnicas (ABNT, 2012).

The statistical analysis was carried out following Associação Brasileira de Normas Técnicas (ABNT, 2011, 2012), and Niva \& Brown (2019). The avoidance (A) behavior was expressed in percentage of the avoidance response of each combination, being calculated by the formula: A $(\%)=((\mathrm{C}-\mathrm{T}) / \mathrm{N}) \times 100$, where $\mathrm{C}$ is the number of individuals observed in the untreated (control) soil, $\mathrm{T}$ is the number of individuals observed in the treated soil, and $\mathrm{N}$ is the total number of individuals per replicate. The avoidance response was analyzed with Fisher's exact test using a one-tailed test, whereas, the dual tests were carried out using a twotailed test (Zar, 1999) to determine no observed effect concentration (NOEC) and lowest observed effect concentration (LOEC). The null hypothesis assumes there is an equal distribution of the individuals in both sides, rejected when $\mathrm{p} \leq 0.05$.

The effect on lethality was determined by the number of survivors or dead enchytraeids after 7 days, and, on reproduction, by the number of juvenile enchytraeids produced after 21 days. The data of enchytraeids were scanned for normality and homogeneity of variances by Levene's test. Posteriorly, each dataset was tested with the one-way analysis of variance, followed by Tukey's test for a pair-wise comparison between treatments and the control, at 5\% probability. A significant reduction in the survival of adult enchytraeids or reproduction measured by the number of juveniles indicates a harmful effect of a given concentration and will determine the NOEC and LOEC among the concentrations tested when compared with the control. The SAS software (SAS Inc., Cary, NC, USA) was used for the calculations.

\section{Results and Discussion}

The dual tests for earthworms and collembolans showed no difference in the distribution of individuals on both sides of the test container ( $\mathrm{p}>0.6$ for $E$. andrei and $\mathrm{p}>0.15$ for $F$. candida) (Figures 1 and 2). At the end of the avoidance test, a survival of 100 and $99 \%$ of the exposed individuals, respectively, was observed. Therefore, both tests were considered valid by ISO 17512-2 (ISO, 2011). The lethality test with enchytraeids showed a survival of 90 and $98 \%$ of the adults in the control group in the TAS and Ferralsol, respectively, meaning that the test was valid according to the recommended criteria of $\geq 80 \%$ survival. The reproduction test was also considered valid, since the control group presented, on average, more than 360 juveniles (minimum of 50 required), with a coefficient of variation lower than $26 \%$ (less than $50 \%$ required), following NBR ISO 16387 (ABNT, 2012; Niva \& Brown, 2019).

The tests with earthworms showed that higher concentrations of biotite schist and phonolite tended to cause increasing avoidance; however, a rate-response relationship was not clear in the range of lower concentrations (Figure 1). Earthworms avoided biotite schist when rock dust concentrations were $10 \%$ or above $(p<0.0001)$ in the TAS and $1.0 \%$ or above in the Arenosol $(\mathrm{p}=0.004)$, and phonolite caused avoidance behavior at $1.0 \%$ or above in both soils $(\mathrm{p} \leq 0.02)$ (Figure 1$)$. Therefore, the derived NOEC value was 1.0 and $0.1 \%$, respectively, for the TAS and Arenosol amended with biotite schist for earthworms, but $0.1 \%$ for both soils with phonolite. It should be noted that these are the maximum concentrations of rock dusts the earthworms are not expected to avoid, whereas the LOEC of biotite is the lowest tested concentration of rock fertilizers the earthworms are expected to avoid. For the TAS and Arenosol amended with biotite schist, the derived LOEC was 10 and $1.0 \%$, respectively, whereas, for both soils treated with phonolite, it was $1.0 \%$. These results show the avoidance behavior of earthworms was stronger towards phonolite than biotite schist. At the concentrations of 1.0 and $10 \%$ biotite schist, a higher variability was observed when compared with the other treatments. Perhaps, the worms presented a less clear reaction towards biotite schist at these concentrations and moved more in and out of the amended soil causing a higher variability in the number of worms found in the control side of the container. 
Collembolans were less sensitive to the tested silicate agrominerals than earthworms, avoiding only the substrate of pure phonolite and TAS amended with $10 \%$ biotite (Figure 2). The NOEC was 1.0 and $10 \%$, respectively, for the TAS and Arenosol amended with biotite schist, and was $10 \%$ for both soils treated with phonolite. The LOEC was 10 and $100 \%$, respectively, for the TAS and Arenosol with biotite schist, and was $100 \%$ for all substrates with phonolite. Differently to the observed for earthworms, collembolans were more sensitive to biotite schist mixed with the TAS than with the Arenosol.
No significant lethality of enchytraeids was verified after 7 days at any of the concentrations of biotite schist mixed with the TAS or Ferralsol, even when the species was exposed to $100 \%$ of both rock dusts (Figure 2). However, the effect of biotite schist on enchytraeid reproduction was significant after exposure to $100 \%$ biotite schist for 21 days. In addition, there was a reduction of $55 \%$ in the offspring (Figure 3). The average number of offspring obtained in all other treatments with the TAS or Ferralsol did not differ from the control, and the NOEC for both agrominerals treated with biotite schist was $10 \%$,
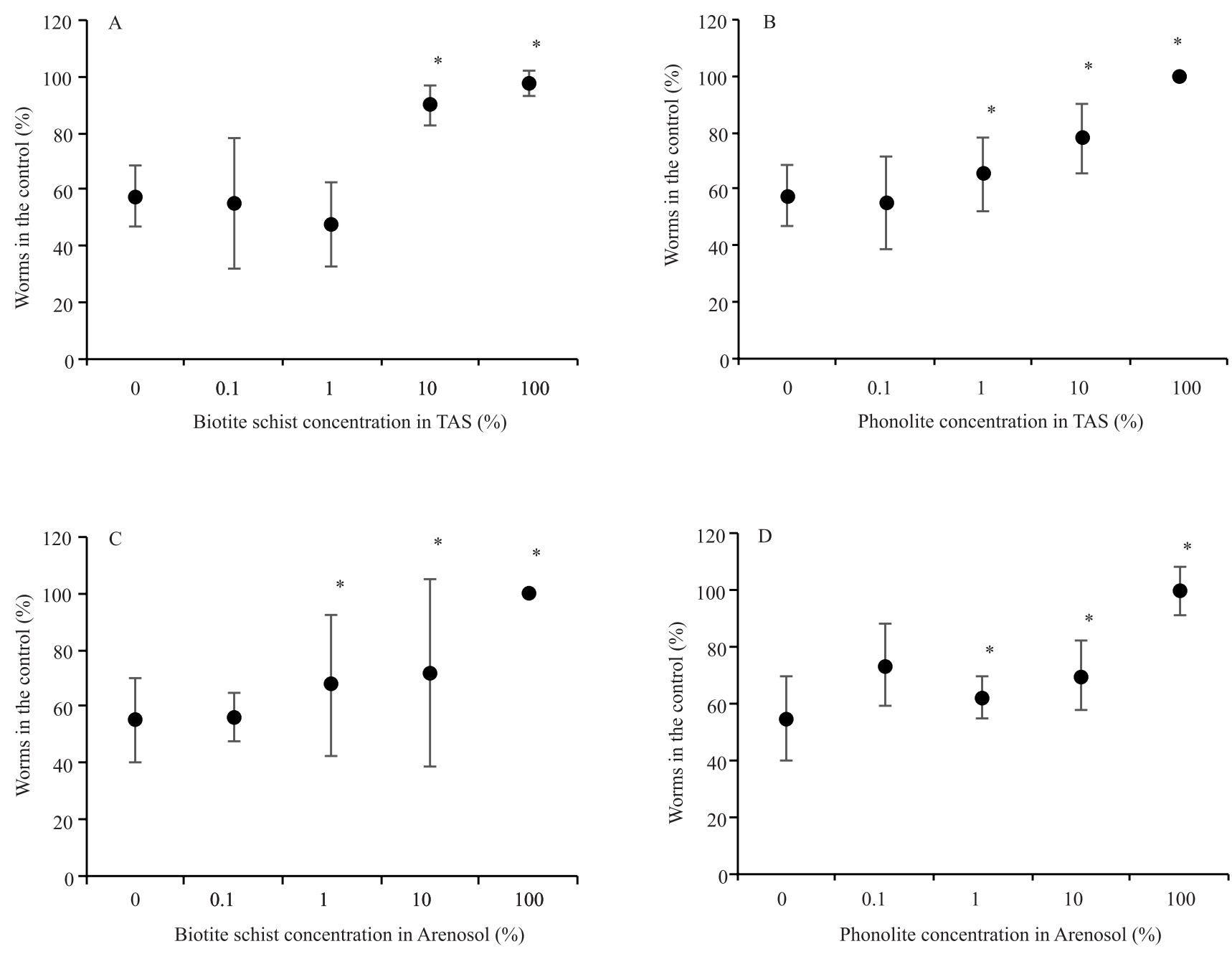

Figure 1. Percentage of Eisenia andrei (average \pm standard deviation) earthworms on the control side of avoidance tests in a tropical artificial soil (TAS) (A and B) and in an Arenosol (C and D) after 48 hours in the presence of different concentrations of biotite schist (A and C) and phonolite (B and D) dusts. ${ }^{*}$ Concentrations of rock where worms significantly avoided treated soils by Fisher's exact test, at 5\% probability. 
whereas the LOEC was $100 \%$. The data did not show the rate-response curve (Figures 2 and 3) required to calculate the median effect concentration.

Phonolite caused a significant lethality after 7 days only when the enchytraeids were exposed to $100 \%$ of each agromineral. A significant reduction in offspring was also observed only in this treatment (Figure 3). Phonolite also did not show a rate-response curve for lethality and reproduction at the tested concentrations. However, the effect of phonolite was higher when it was mixed with the Ferralsol rather than with the TAS, suggesting a possible influence of soil type on the rock dust effect.
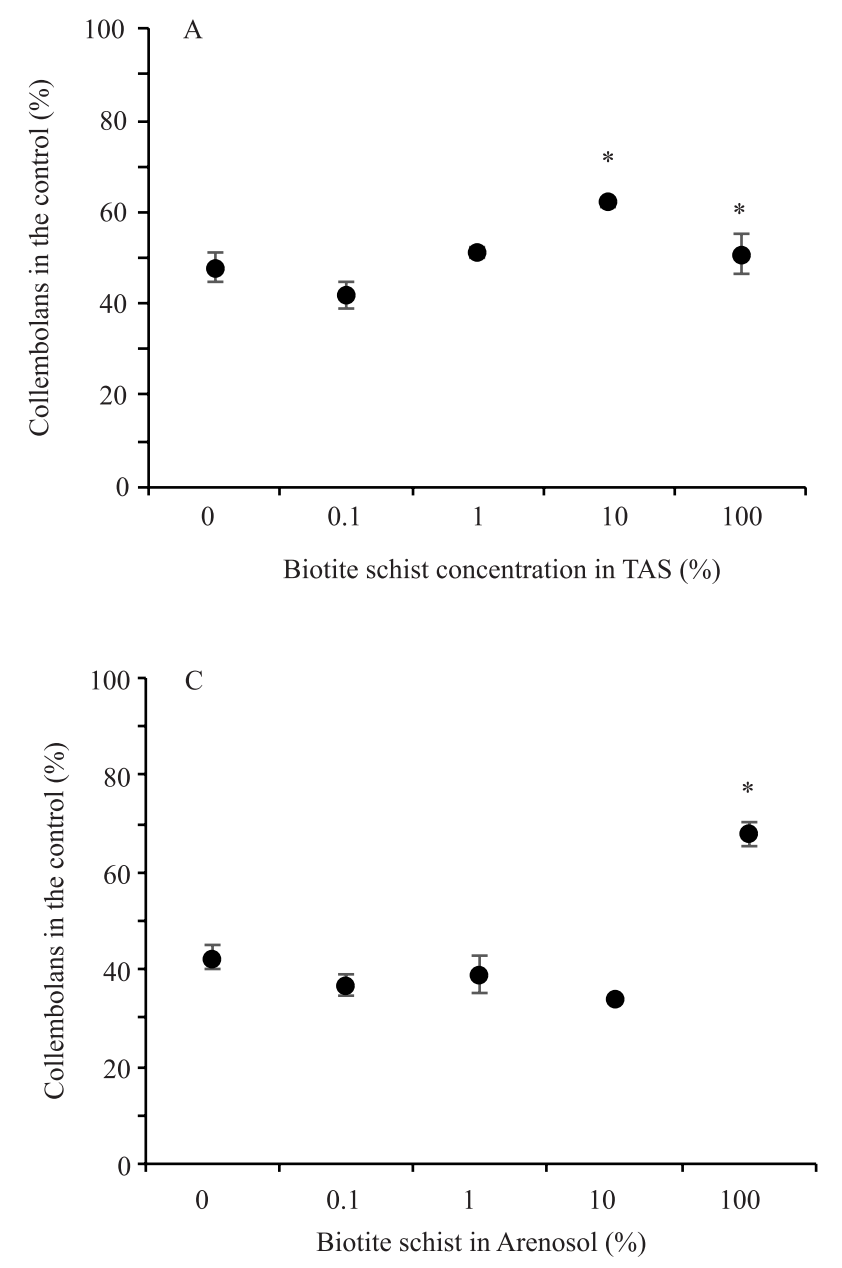

A comparison of the soils revealed that the Ferralsol had $5 \%$ less clay and less organic matter than the TAS, while the Arenosol had even less clay and organic matter (Table 1). The differences in clay were not so contrasting and the results comparing the TAS and both soils did not show a consistent pattern. Among the three evaluated soils, the TAS presented the highest $\mathrm{pH}$, a condition that reduces rock dust dissolution, as stated by Bolland \& Baker (2000). This condition combined with a higher amount of organic matter could result in a possible smaller effect in the TAS, which could explain the results observed for earthworm avoidance behavior toward biotite (Figure 1) but not the stronger
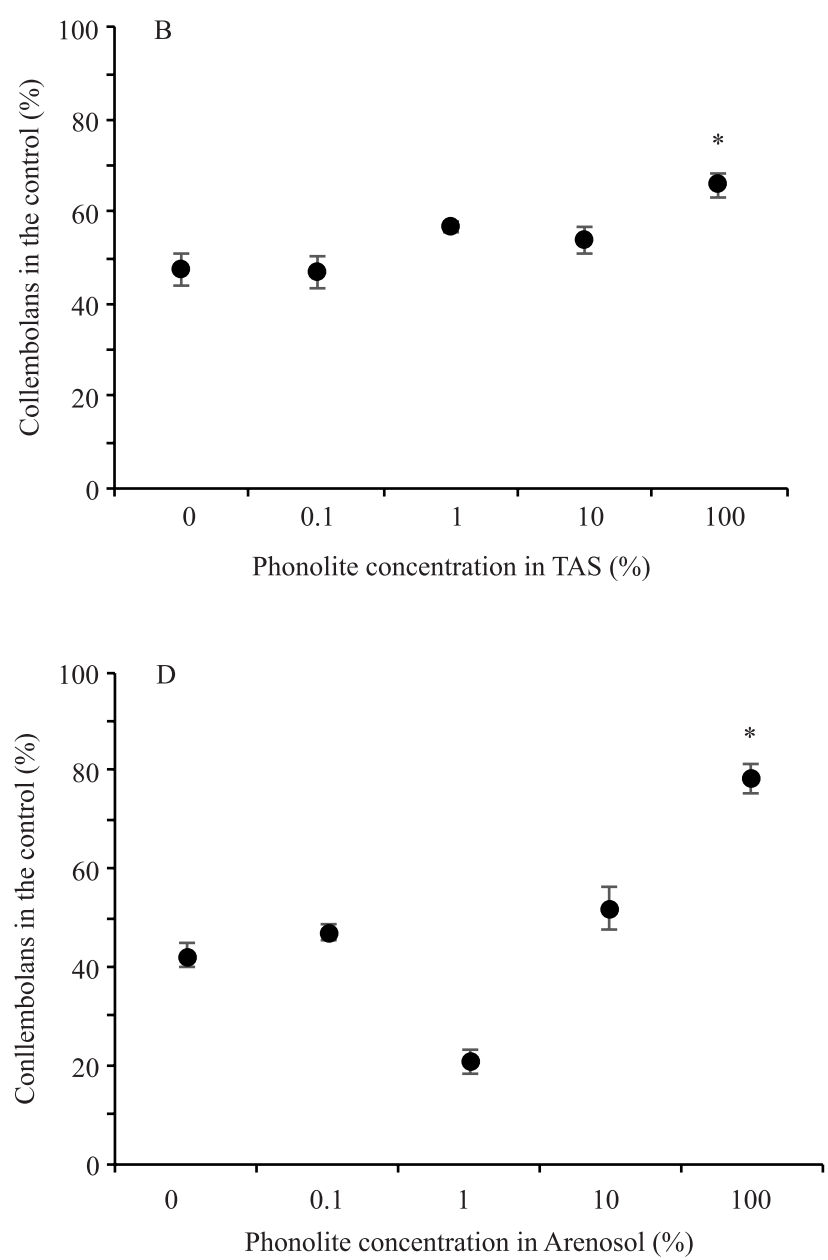

Figure 2. Percentage of Folsomia candida (average \pm standard deviation) collembolans on the control side of avoidance tests in a tropical artificial soil (TAS) (A and B) and in an Arenosol (C and D) after 48 hours in the presence of different concentrations of biotite schist (A and C) and phonolite (B and D) dusts. *Concentrations of rock where worms significantly avoided treated soils by Fisher's exact test, at 5\% probability. 
effect on collembolan behavior in the same soil (Figure 2). Therefore, soil type seems to influence, at least to some degree, the effect of rock dusts on the behavior of invertebrates; however, more studies are necessary to understand this interaction.

No report on the effect of agrominerals on soil fauna behavior was found in the literature. However, rock dust could interfere with the condition of the habitat for invertebrates by changing the physical quality of the soil. Singhal et al. (2020), for example, found that fine particles of stone waste dust and sandstone were able to increase the density and reduce the porosity and hydraulic conductivity of the soil, changing water dynamics. In the present study, the avoidance behavior was more marked at higher concentrations and for phonolite, whose particles are finer $(<0.15 \mathrm{~mm})$ than those of biotite $(<0.3 \mathrm{~mm})$. Rock particles smaller than $0.4 \mathrm{~mm}$ were also reported to cause a reduction
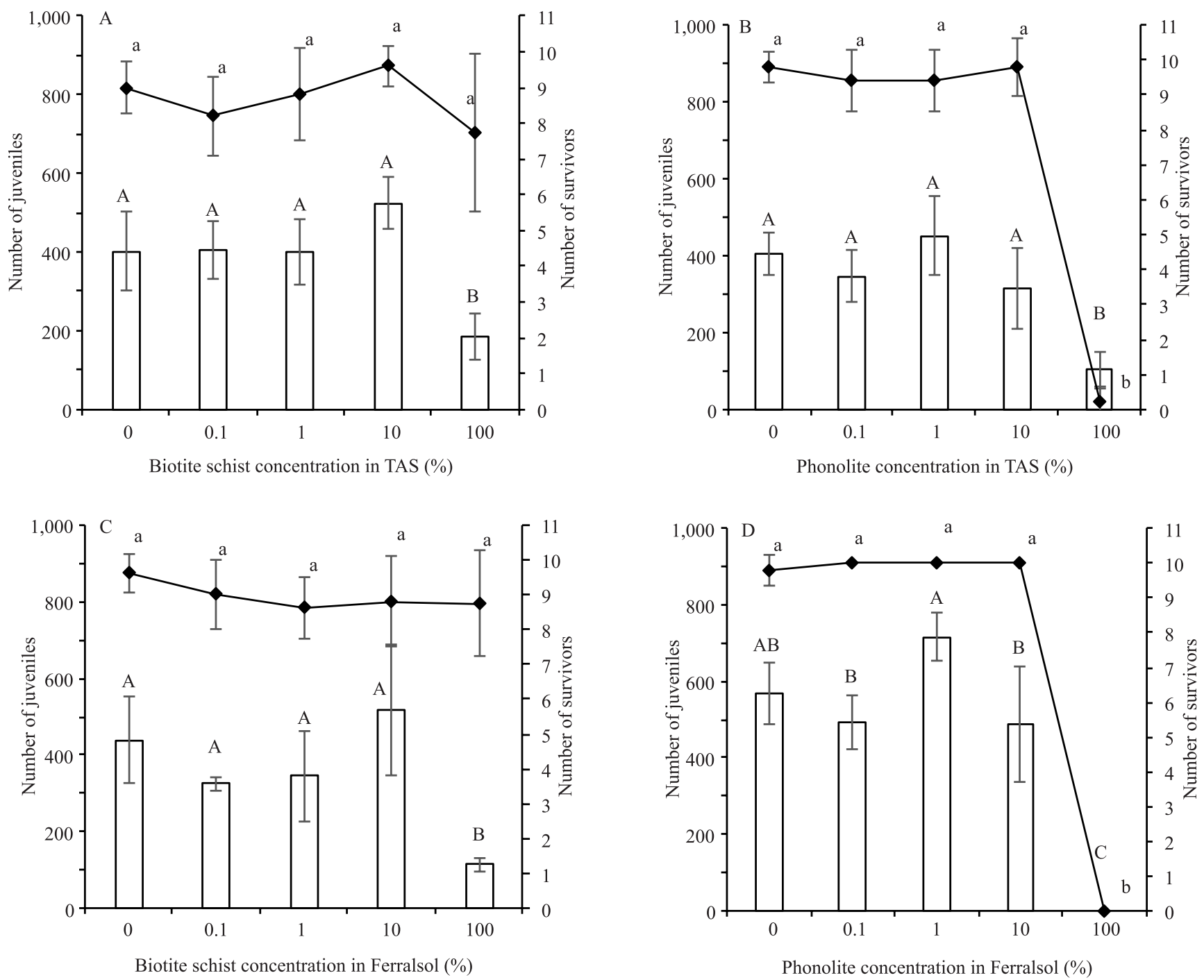

Figure 3. Number of juveniles ( $\mathrm{x} \pm$ standard deviation) and of surviving adults of Enchytraeus $\mathrm{sp}$. ( $\mathrm{x} \pm$ standard deviation) after 21 (open bars) and 7 (continuous line) days, respectively, of exposition to different concentrations of biotite schist (A and C) and phonolite (B and D) dusts, mixed with a tropical artificial soil (TAS) (A and B) and a Ferralsol (C and D). Equal uppercase letters indicate no statistical difference in the number of juveniles and equal lowercase letters indicate no difference between the number of survivors by the analysis of variance and Tukey's test $($ alpha $=0.05)$. The lethality and reproduction tests were performed independently. 
in soil porosity, with a consequent compaction when $300 \mathrm{Mg} \mathrm{ha}^{-1}$ basalt dust rock was used to amend the soil (Knapik \& Angelo, 2007). This condition was considered less favorable to plants and, therefore, might also affect earthworms. Furthermore, Erktan et al. (2020) concluded that physical attributes could influence trophic interactions by limiting the connectivity and mobility of organisms through the pores in the soil. Therefore, changes in behavior caused by increased rock dust concentrations might be harmful to ecosystem functioning. In field conditions, rock amendments could hinder the colonization by earthworms and other sensitive organisms, causing a consequent temporary loss or reduction in ecosystem services.

The addition of agrominerals to the substrates caused an increase in $\mathrm{pH}$, electrical conductivity, and salt content at the higher concentrations, mainly when phonolite was mixed with the Ferralsol. The observed $\mathrm{pH}$ was higher than that of control, being 4.8 to 5.8 at the concentration of $1.0 \%$ phonolite mixed with the Ferralsol and 5.7 to 6.3 at the concentration of $10 \%$ mixed with the TAS, reaching $\mathrm{pH} 9.6$ at $100 \%$ rock. Phonolite increased electrical conductivity from 54 to $89 \mu \mathrm{S} \mathrm{cm}^{-1}$ (25 and $42 \mathrm{mg} \mathrm{L}^{-1}$ total dissolved solids), when mixed with the Ferralsol at $1.0 \%$, and from 90 to $97 \mu \mathrm{S} \mathrm{cm}^{-1}$ (43 and $46 \mathrm{mg} \mathrm{L}^{-1}$ total dissolved solids), when mixed with the TAS at the same concentration; in pure rock dust, the electrical conductivity and salt concentration were almost five times higher than in the Ferralsol (Tables 1 and 2). However, pure biotite schist showed much lower values of $91 \mu \mathrm{S} \mathrm{cm}^{-1}$ and $43 \mathrm{mg} \mathrm{L}^{-1}$, respectively. Therefore, when the agrominerals were mixed with the soils, these parameters did not increase as much for phonolite. At the concentration of $10 \%$ biotite in the TAS, for example, salt and conductivity were increased in only $22 \%$ (43 to $53 \mathrm{mg} \mathrm{L}^{-1}$ and 90 to $110 \mu \mathrm{S} \mathrm{cm}^{-1}$, respectively). When biotite was mixed with the Ferralsol, the changes in these two parameters were not clear, with conductivity ranging from 48 to $54 \mu \mathrm{S} \mathrm{cm}^{-1}$.

In most cases, the two tested silicate agrominerals caused a significant negative effect on the behavior or reproduction of soil invertebrates, specially using concentrations equal to $10 \%$ or pure rock dusts, except for earthworms, which avoided soils with rock fertilizers starting at 1.0\% (Figures 1, 2, and 3). The increase in electrical conductivity, salt content, and $\mathrm{pH}$ at higher rates may explain the potentially stronger negative effects of these concentrations on soil invertebrates. In particular for oligochaetes, which are soft-bodied animals breathing through a wet epidermis, a soil with increased amounts of salts may be deleterious or cause some kind of discomfort due to changes in osmotic conditions. This could explain, in part, the observed effects at higher concentrations and the sensitivity of earthworms to the agrominerals, mainly to phonolite, which is richer in soluble salts, particularly sodium (Table 1). The availability of phonolite sodium tends to be high (von Wilpert \& Lukes, 2003) and can be a limiting factor at high rates in the soil. The effect of phonolite on oligochaetes was stronger than that of biotite schist apparently because of substrate texture changes and a higher salt content at higher concentrations, but more tests are required to confirm this.

Therefore, soil salinization has been reported to affect earthworms and other organisms. Combinations of salts with different ionic properties in the soil were shown to have effects on earthworm lethality and growth (Owojori \& Heinecke, 2014). Earthworm avoidance behavior was also found to be negatively affected by drilling waste from oil wells, at a concentration of $234 \mathrm{Mg} \mathrm{ha}^{-1}$ (Machado et al., 2018). Although the studied material was rich in barium and sodium, the authors found the latter salt to be more restrictive to earthworms than the former. Alves et al. (2015) tested the ecotoxicological effect of sugarcane vinasse - a waste of ethanol production used as an alternative fertilizer in agricultural soils - on earthworms, enchytraeids, mites, and collembolans. The authors concluded that two types of vinasses reduced the reproduction of the three first organisms at the highest concentrations (120 to $294 \mathrm{~mL} \mathrm{~kg}^{-1}$ dry weight), probably because of the higher salt content, especially of potassium $\left(3,350\right.$ to $9,200 \mathrm{mg} \mathrm{dm}^{-1}$ for pure vinasses).

It should be noted that the use of agrominerals does not cause soil salinization because only low concentrations are generally applied; however, it is important to consider the possible effects of the presence of different salts and be careful with repeated applications or combinations with other materials. The results obtained in the present study suggest that the presence of salt contributed to the higher sensitivity of earthworms to agrominerals at higher concentrations 
(Figures 1 and 2). Oligochaetes may be more exposed and, consequently, more susceptible to a contaminated soil than collembolans because they ingest soil and move by crawling on its surface or burrowing litter and soil, whereas collembolans (small arthropods) live on plant litter, fragmenting organic matter, and feeding on microorganisms (Jänsch et al., 2005). However, the salts in the soil may not be deleterious in all situations. Silva et al. (2015) showed that a saline soil with $15 \%$ sodium stimulated the reproduction of the enchytraeid Enchytraeus albidus Henle 1837, although it decreased its survival. Similarly, in the present study, a higher number of juvenile enchytraeids could be observed at concentrations of 1.0 or $10 \%$ rock, when compared with the control (Figure 3). It is not uncommon for low concentrations of substances to stimulate the reproduction of enchytraeids (Segat et al., 2015; Silva et al., 2015). However, an increased population of a species might not always be considered a positive effect if it causes disturbances in the ecosystem. Therefore, more tests with other concentration ranges are desirable for clarification.

The ideal rates of potassium silicate rock dust for soil amendment depend on the amount of potassium recommended for a specific culture and rock concentration of $\mathrm{K}_{2} \mathrm{O}$. Mancusoetal.(2014), for example, found that coffee (Coffea arabica $\mathrm{L}$.) yields improved with the application of $150 \mathrm{~kg} \mathrm{ha}^{-1} \mathrm{~K}_{2} \mathrm{O}$ phonolite $(8.0 \%$ $\mathrm{K}_{2} \mathrm{O}$ ), but that $300 \mathrm{~kg} \mathrm{ha}^{-1}$ proved to be excessive for this crop. Since the biotite schist and phonolite used in the present study contain $3.0-8.0 \% \mathrm{~K}_{2} \mathrm{O}$ (Table 2), the application rates of agrominerals to achieve $300 \mathrm{~kg}$ ha $^{-1} \mathrm{~K}_{2} \mathrm{O}$ would be roughly $10.0-4.0$ tons of rock dust, which would be equivalent to approximately $0.2-0.5 \%$ rock dust per hectare respectively, considering $2.0 \mathrm{Mg}$ soil in 1.0 ha. Furthermore, a life cycle assessment for basalt rock revealed that a conceivable rock dust rate would be roughly $1.8 \mathrm{Mg} \mathrm{ha}^{-1}$ (approximately $0.09 \%$ rock dust), considering the transportation costs of extraction, delivery, and application, as well as carbon sequestration potential, within the state of São Paulo, Brazil, where farmers generally use $5.5 \mathrm{Mg}$ ha $^{-1}$ (approximately $0.27 \%$ rock dust) (Lefebvre et al., 2019). Therefore, according to these numbers, it can be inferred that the rates of biotite schist and phonolite used for soil amendment are lower than the NOEC values for the soil invertebrate tests. However, the significant avoidance effect observed for earthworms at agromineral concentrations equal to $1.0 \%$ requires attention. If a safety factor of 10 is applied to the NOEC for earthworms in order to obtain safe levels to protect the ecosystem (van Gestel, 2012), a concentration of $0.1 \%$ rock would be in a range of caution. Therefore, there is a chance that the recommended rates may impact soil invertebrates that are more sensitive, such as earthworms.

The use of biotite schist and phonolite for soil amendment presented a low risk for the three soil invertebrates evaluated, refuting the initial hypothesis. However, caution is needed when defining the rates of silicate agrominerals for soil amendment due to the risk of higher concentrations affecting the function of the soil as a habitat for invertebrates. Depending on their salt content and granulometry, soils amended with higher rates of agrominerals might prevent or reduce their colonization or re-colonization by invertebrates. The interaction with soil properties is also important to be considered when determining safe agromineral rates. Therefore, tests should be repeated with other types of rocks, organisms and natural soils, as well as in the field, to confirm to what extent agrominerals could affect soil biota and, consequently, the environmental sustainability of this kind of agricultural practice. This information would be useful in predicting rates of agrominerals capable of sustaining/impairing the function of the soil as a habitat.

\section{Conclusions}

1. The agrominerals biotite schist and phonolite are not expected to negatively affect earthworms, collembolans, and enchytraeids when applied to the soil at concentrations lower than 1.0\% (approximately $20 \mathrm{Mg} \mathrm{ha}^{-1}$ ) rock dust.

2. The effect of soils amended with phonolite dust on earthworm behavior is greater than that of soils mixed with biotite schist, but the risk to the quality of the soil as a habitat is low when the agromineral is applied at the agronomically recommended rates.

3. Earthworm and collembolan avoidance behavior and enchytraeid reproduction are affected by pure biotite schist and phonolite dusts.

4. Agrominerals can change soil properties, such as granulometry and $\mathrm{pH}$, modifying the soil condition as a habitat and consequently affecting the behavior of the tested organisms. 


\section{Acknowledgments}

To Empresa Brasileira de Pesquisa Agropecuária (Embrapa), for financial support (SEG 02.14.10.002.00.00); and to Conselho Nacional de Desenvolvimento Científico e Tecnológico (CNPq), for research productivity grant (CNPq 305939/2018-1).

\section{References}

ABNT. Associação Brasileira de Normas Técnicas. NBR ISO 16387: qualidade do solo: efeitos de poluentes em Enchytraeidae (Enchytraeus sp.): determinação de efeitos sobre reprodução e sobrevivência. Rio de Janeiro, 2012. 29p.

ABNT. Associação Brasileira de Normas Técnicas. NBR ISO 17512-1: qualidade do solo: ensaio de fuga para avaliar a qualidade de solos e efeitos de substâncias químicas no comportamento: parte 1: ensaio com minhocas (Eisenia fetida e Eisenia andrei). Rio de Janeiro, 2011. 26p.

ALVES, P.R.L.; NATAL-DA-LUZ, T.; SOUSA, J.P.; CARDOSO, E.J.B.N. Ecotoxicological characterization of sugarcane vinasses when applied to tropical soils. Science of the Total Environment, v.526, p.222-232, 2015. DOI: https://doi.org/10.1016/j. scitotenv.2015.03.150.

BARETTA, D.; BARTZ, M.L.C.; FACHINI, I.; ANSELMI, R.; ZORTÉA, T.; BARETTA, C.R.D.M. Soil fauna and its relation with environmental variables in soil management systems. Revista Ciência Agronômica, v.45, p.871-879, 2014. DOI: https://doi.org/10.1590/S1806-66902014000500002.

BLASKOWSKI, A.E.; RIOS, D.C.; CONCEIÇÃO, H.; MARIANI, B.B. Potencial agromineral das rochas de descarte da mina de cromita Ipueira, Bahia. Anuário do Instituto de Geociências, v.42, p.355-373, 2019. DOI: https://doi.org/10.11137/2019_1_355_373.

BOLLAND, M.D.A.; BAKER, M.J. Powdered granite is not an effective fertilizer for clover and wheat in sandy soils from Western Australia. Nutrient Cycling in Agroecosystems, v.56, p.59-68, 2000. DOI: https://doi.org/10.1023/A:1009757525421.

BRASIL. Ministério da Agricultura, Pecuária e Abastecimento. Instrução Normativa ${ }^{\circ}$ 5, de 10 de março de 2016. [Estabelece as regras sobre definições, classificação, especificações e garantias, tolerâncias, registro, embalagem, rotulagem e propaganda dos remineralizadores e substratos para plantas, destinados à agricultura]. Diário Oficial da União, 14 mar. 2016. Seção1, p.1092.

BROWN, G.G.; NIVA, C.C.; ZAGATTO, M.R.G.; FERREIRA, S. de A.; NADOLNY, H.S.; CARDOSO, G.B.X.; SANTOS, A.; MARTINEZ, G. de A.; PASINI, A.; BARTZ, M.L.C.; SAUTTER, K.D.; THOMAZINI, M.J.; BARETTA, D.; SILVA, E. da; ANTONIOLLI, Z.I.; DECAËNS, T.; LAVELLE, P.M.; SOUSA, J.P.; CARVALHO, F. Biodiversidade da fauna do solo e sua contribuição para os serviços ambientais. In: PARRON, L.M.; GARCIA, J.R.; OLIVEIRA, E.B. de; BROWN, G.G.; PRADO, R.B. (Ed.). Serviços ambientais em sistemas agrícolas e florestais do Bioma Mata Atlântica. Brasília: Embrapa, 2015. cap.10, p.121-154.
CLAESSEN, M.E.C. (Org.). Manual de métodos de análises de solo. 2.ed. rev. e atual. Rio de Janeiro: Embrapa-CNPS, 1997. 212p. (Embrapa-CNPS. Documentos, 1).

DJURIŠIĆ, A.B.; LEUNG, Y.H.; NG, A.M.C.; XU, X.Y.; LEE, P.K.H.; DEGGER, N.; WU, R.S.S. Toxicity of metal oxide nanoparticles: mechanisms, characterization, and avoiding experimental artefacts. Small, v.11, p.26-44, 2015. DOI: https://doi.org/10.1002/smll.201303947.

EDWARDS, D.P.; LIM, F.; JAMES, R.H.; PEARCE, C.R.; SCHOLES, J.; FRECKLETON, R.P.; BEERLING, D.J. Climate change mitigation: potential benefits and pitfalls of enhanced rock weathering in tropical agriculture. Biology Letters, v.13, art.20160715, 2017. DOI: https://doi.org/10.1098/rsbl.2016.0715.

ERKTAN, A.; OR, D.; SCHEU, S. The physical structure of soil: determinant and consequence of trophic interactions. Soil Biology and Biochemistry, v.148, art.107876, 2020. DOI: https://doi.org/10.1016/j.soilbio.2020.107876.

GUARESCHI, R.F.; BODDEY, R.M.; ALVES, B.J.R.; SARKIS, L.F.; MARTINS, M. dos R.; JANTALIA, C.P.; CABRIALES, J.J.P.; NÚÑEZ, J.A.V.; URQUIAGA, S. Balanço de nitrogênio, fósforo e potássio na agricultura da América Latina e o Caribe. Terra Latinoamericana, v.37, p.105-119, 2019. DOI: https://doi.org/10.28940/terra.v37i2.423.

ISO. International Organization for Standardization. ISO 11267: soil quality: inhibition of reproduction of collembola (Folsomia candida) by soil pollutants. Geneve, 1999.

ISO. International Organization for Standardization. ISO 175122: soil quality: avoidance test for determining the quality of soils and effects of chemicals on behaviour: part 2: test with collembolans (Folsomia candida). Geneve, 2011.

IUSS WORKING GROUP WRB. World Reference Base for Soil Resources 2014: international soil classification system for naming soils and creating legends for soil maps: update 2015. Rome: FAO, 2015. (FAO. World Soil Resources Reports, 106).

JÄNSCH, S.; AMORIM, M.J.; RÖMBKE, J. Identification of the ecological requirements of important terrestrial ecotoxicological test species. Environmental Reviews, v.13, p.51-83, 2005. DOI: https://doi.org/10.1139/a05-007.

KNAPIK, J.G.; ANGELO, A.C. Pó de basalto e esterco eqüino na produção de mudas de Prunus sellowii Koehne (Rosaceae). Floresta, v.37, p.427-436, 2007. DOI: https://doi.org/10.5380/ rf.v37i3.9939.

LEFEBVRE, D.; GOGLIO, P.; WILliAMS, A.; MANNING, D.A.C; AZEVEDO, A.C. de; BERGMANN, M.; MEERSMANS, J.; SMITH, P. Assessing the potential of soil carbonation and enhanced weathering through Life Cycle Assessment: a case study for Sao Paulo State, Brazil. Journal of Cleaner Production, v.233, p.468-481, 2019. DOI: https://doi.org/10.1016/j. jclepro.2019.06.099.

MACHADO, H.M.; AMARAL SOBRINHO, N.M.B. do; CORREIA, M.E.F.; MAGALHÃES, M.O.L.; LIMA, E.S.A. Toxicity of drilling waste from oil wells on oligochaeta. Floresta e Ambiente, v.25, e20160320, 2018. DOI: https://doi.org/10.1590/2179-8087.032016. 
MANCUSO, M.A.C.; SORATTO, R.P., CRUSCIOL, C.A.C.; CASTRO, G.S.A. Effect of potassium sources and rates on Arabica coffee yield, nutrition, and macronutrient export. Revista Brasileira de Ciência do Solo, v.38, p.1448-1456, 2014. DOI: https://doi.org/10.1590/S0100-06832014000500010.

MARTINS, E. de S.; RESENDE, A.V. de; OLIVEIRA, C.G. de; FURTINI NETO, A.E. Materiais silicáticos como fontes regionais de nutrientes e condicionadores de solos. In: FERNANDES, F.R.C.; LUZ; A.B. da; CASTILHOS, Z.C. (Ed.). Agrominerais para o Brasil. Rio de Janeiro: Centro de Tecnologia Mineral, 2010. p.89-104.

NIVA, C.C.; BROWN, G.G. (Ed.). Ecotoxicologia terrestre: métodos e aplicações dos ensaios com oligoquetas. Brasília: Embrapa, 2019. 258p.

OWOJORI, O.J.; REINECKE, A.J. Differences in ionic properties of salts affect saline toxicity to the earthworm Eisenia fetida. Applied Soil Ecology, v.83, p.247-252, 2014. DOI: https://doi.org/10.1016/j.apsoil.2013.05.019.

RESENDE, A.V. de; MACHADO, C.T.T.; MARTINS, E. de S.; SENA, M.C. de; NASCIMENTO, M.T. do; SILVA, L. de C.R.; LINHARES, N.W. Rochas como fontes de potássio e outros nutrientes para culturas anuais. Espaço \& Geografia, v.9, p.135$161,2006$.

SANTOS, H.G. dos; JACOMINE, P.K.T.; ANJOS, L.H.C. dos; OLIVEIRA, V.Á. de; LUMBRERAS, J.F.; COELHO, M.R.; ALMEIDA, J.A. de; ARAÚJO FILHO, J.C. de; OLIVEIRA, J.B. de; CUNHA, T.J.F. Sistema brasileiro de classificação de solos. 5.ed. rev. e ampl. Brasília: Embrapa, 2018. 356p.
SEGAT, J.C.; ALVES, P.R.L.; BARETTA, D.; CARDOSO, E.J.B.N. Ecotoxicological evaluation of swine manure disposal on tropical soils in Brazil. Ecotoxicology and Environmental Safety, v.122, p.91-97, 2015. DOI: https://doi.org/10.1016/j. ecoenv.2015.07.017.

SILVA, A.L.P.; AMORIM, M.J.B.; HOLMSTRUP, M. Salinity changes impact of hazardous chemicals in Enchytraeus albidus. Environmental Toxicology and Chemistry, v.34, p.2159-2166, 2015. DOI: https://doi.org/10.1002/etc.3058.

SINGHAL, A.; GOEL, S.; SENGUPTA, D. Physicochemical and elemental analyses of sandstone quarrying wastes to assess their impact on soil properties. Journal of Environmental Management, v.271, art.111011, 2020. DOI: https://doi.org/10.1016/j.jenvman.2020.111011.

VAN GESTEL, C.A.M. Soil ecotoxicology: state of the art and future directions. Zookeys, v.176, p.275-296, 2012. DOI: https://doi.org/10.3897/zookeys.176.2275.

VAN STRAATEN, P. Farming with rocks and minerals: challenges and opportunities. Anais da Academia Brasileira de Ciências, v.78, p.731-747, 2006. DOI: https://doi.org/10.1590/ S0001-37652006000400009.

VON WILPERT, K.; LUKES, M. Ecochemical effects of phonolite rock powder, dolomite and potassium sulfate in a spruce stand on an acidified glacial loam. Nutrient Cycling in Agroecosystems, v.65, p.115-127, 2003. DOI: https://doi.org/10.1023/A:1022103325310.

ZAR, J.H. Biostatistical analysis. $4^{\text {th }}$ ed. London: Prentice-Hall, 1999. 663p. 